\title{
DNA HOMOLOGY STUDIES IN STREPTOMYCES USING S1 NUCLEASE
}

\author{
Tamotsu Furumai, Masayuki Sudoh, Sayoko Sawairi \\ and Hiromi B. MARUYAMA \\ Department of Microbiology and Chemotherapy, Nippon Roche Research Center \\ 200 Kajiwara, Kamakura, Kanagawa 247, Japan
}

(Received for publication December 20, 1983)

\begin{abstract}
The optimal reaction conditions for the determination of DNA-homology in Streptomyces species were established in the presence of formamide using $\mathrm{S} 1$ nuclease. The melting temperature of Streptomyces DNA was $90^{\circ} \mathrm{C}$ in $0.42 \mathrm{M} \mathrm{NaCl}$ containing $20 \%$ formamide in which the denaturation was completed by boiling for 5 minutes. In the $\mathrm{S} 1$ reaction mixture consisting of $5 \mathrm{U}$ of $\mathrm{S} 1$ nuclease, $0.168 \mathrm{M} \mathrm{NaCl}, 1 \mathrm{mM} \mathrm{ZnSO}_{4}$ and $8 \%$ formamide at $\mathrm{pH} 4.8$, single-stranded DNA was hydrolyzed by more than $98 \%$, while the hydrolysis of doublestranded DNA was less than $3 \%$. From the analysis of homoduplex formation, the $\mathrm{C}_{0} \mathrm{t} 1 / 2$ was found at 20 hours, when a mixture of unlabeled DNA and index DNA was used at a ratio of 500: 1 .
\end{abstract}

In 1975, BARTH and GRINTER ${ }^{1)}$ investigated the assay conditions for DNA homology determination by S1 nuclease method and recommended their method as the most suitable and precise one applicable to most bacteria. However, there is some difficulty in applying this method to actinomycetes. For example, since melting temperature ( $\mathrm{Tm}$ ) of Streptomyces DNA ranges from 98 to $100^{\circ} \mathrm{C}$ due to its high GC content ${ }^{2,3,4}$, the denaturation reaction should be carried out at a temperature as high as $110^{\circ} \mathrm{C}$ or even higher. Coykendall and Munzenmaier ${ }^{5)}$ used $115 \sim 120^{\circ} \mathrm{C}$ for denaturation and $70^{\circ} \mathrm{C}$ for reassociation of an Actinomyces DNA in $0.42 \mathrm{M} \mathrm{NaCl}$. On the other hand, as MARMur and Doty pointed out ${ }^{\text {) }}$, for the reassociation reaction, it is desirable to start at $25^{\circ} \mathrm{C}$ below the $\mathrm{Tm}$ to obtain the maximal rate. Conditions for assaying DNA homology in Streptomyces using S1 nuclease must thus be optimized because the determination of DNA homology is indispensable to identify or classify various species in actinomycetes.

We undertook a series of studies employing nuclease S1 and a denaturing agent formamide. In this paper we describe a simplified and convenient method for a DNA homology test in Streptomyces.

\section{Materials and Methods}

\section{Microorganisms and Media}

Streptomyces dimorphogenes NR-320-OM7HB ${ }^{\text {7) }}$, which produces trestatins ${ }^{8)}$, was grown for 48 hours at $28^{\circ} \mathrm{C}$ in $100 \mathrm{ml}$ of Trypticase Soy Broth (BBL) containing $0.1 \%$ glycine. Escherichia coli $\mathrm{K}-12$ was grown for 16 hours at $37^{\circ} \mathrm{C}$ in $100 \mathrm{ml}$ of LB broth consisting of Bacto-tryptone $0.1 \%$, Bactoyeast extract $0.05 \%$ and $\mathrm{NaCl} 0.05 \%$.

Isolation and Purification of DNA

DNA of E. coli was extracted and purified by the method described by MARMUR ${ }^{8)}$. For isolation and purification of Streptomyces DNA, a modification of the method of CHATER et al. ${ }^{10)}$ was used as described below. 
Cells, harvested by centrifugation for 15 minutes at $7,500 \times g$ at $4^{\circ} \mathrm{C}$, were washed with $\mathrm{P}_{3}$ medium ${ }^{11)}$, suspended in $20 \mathrm{ml}$ of the same medium containing $20 \mathrm{mg}$ of lysozyme (Sigma) and $1 \mathrm{mg}$ of $N$-acetylmuramidase (Seikagaku Kogyo), and then incubated for $0.5 \sim 1$ hour at $30^{\circ} \mathrm{C}$. To protoplasts thus obtained was added $3 \mathrm{ml}$ of $0.1 \mathrm{M}$ Tris buffer $(\mathrm{pH} 8)$ containing $10 \%$ sodium dodecyl sulfate (SDS) and $1 \mathrm{ml}$ of $0.25 \mathrm{M}$ ethylenediaminetetraacetate (EDTA). The mixture was incubated for 20 minutes at $50^{\circ} \mathrm{C}$ and then chilled in ice for 10 minutes. The DNA was extracted twice with $15 \mathrm{ml}$ of cold phenol $-0.1 \%$ 8-hydroxyquinoline saturated with TE (10 mM Tris, pH 7.5 plus $1 \mathrm{~mm}$ EDTA) containing $0.1 \mathrm{M} \mathrm{NaCl}$ and $5 \mathrm{ml}$ of cold chloroform. After being centrifuged for 15 minutes at $3,700 \times g$, the supernatant was recentrifuged for 20 minutes at $27,000 \times g$ at $4^{\circ} \mathrm{C}$. The DNA was precipitated with two volumes of cold ethanol, and collected with a glass-rod. This crude DNA was dissolved in $20 \mathrm{ml}$ of $0.1 \times \mathrm{SSC}(15 \mathrm{~mm} \mathrm{NaCl}$ plus $1.5 \mathrm{~mm}$ sodium citrate, $\mathrm{pH} 7.0)$, and incubated for 20 minutes at $37^{\circ} \mathrm{C}$ with $50 \mu \mathrm{g} / \mathrm{ml}$ of ribonuclease A (Sigma) followed by incubation for 20 minutes at $37^{\circ} \mathrm{C}$ with Pronase E (Kaken Seiyaku Co., Ltd.) at $100 \mu \mathrm{g} / \mathrm{ml}$. After phenol extraction, the supernatant was extracted with $20 \mathrm{ml}$ of chloroform - isoamyl alcohol (24:1), and then reprecipitated with cold ethanol. The DNA was dissolved in $10 \mathrm{ml}$ of $0.1 \times$ SSC and dialyzed against $0.1 \times$ SSC overnight.

The concentration of DNA was determined by absorption of ultraviolet light at $260 \mathrm{~nm}$. The ratios of absorption of $230: 260: 280 \mathrm{~nm}$ were about $0.42: 1: 0.52$.

Preparation of ${ }^{3} \mathrm{H}$-labeled DNA

The unsheared DNA purified by the procedure described above was labeled by the nick translation $^{12,13)}$. A $50 \mu \mathrm{l}$ of reaction mixture contained $2 \mu \mathrm{g}$ of DNA, $5 \mu \mathrm{l}$ of $10 \times \mathrm{NT}$ buffer $(0.5 \mathrm{M}$ Tris, $\mathrm{pH} 7.5,0.1 \mathrm{M} \mathrm{MgSO}_{4}, 10 \mathrm{~mm}$ dithiothreitol, $0.5 \mathrm{mg}$ of bovine serum albumin per $\mathrm{ml}$ and $25 \%$ glycerol), $5 \mu 1$ of $0.3 \mathrm{~mm}$ each of deoxyadenosine $5^{\prime}$-triphosphate, deoxyguanosine $5^{\prime}$-triphosphate and thymidine $5^{\prime}$-triphosphate, and $5 \mu \mathrm{Ci}$ of deoxy- $\left[5-{ }^{3} \mathrm{H}\right]$ cytidine 5 'triphosphate $(19 \mathrm{Ci} / \mathrm{mm}$, Amersham), as well as $7 \mathrm{ng}$ of DNase I (Miles Lab., Inc.). The reaction was allowed to proceed for 2 minutes at room temperature, for 5 minutes in ice, and then kept for 1 hour at $14^{\circ} \mathrm{C}$ after adding $1 \mu \mathrm{l}$ of $\mathrm{E}$. coli DNA polymerase I (Takara Shuzo Co., Ltd., final concentration: $14 \mathrm{U} / \mathrm{ml}$ ). The reaction was terminated by adding $50 \mu \mathrm{l}$ of TE buffer and $10 \mu \mathrm{l}$ of $0.25 \mathrm{M}$ EDTA at pH 8 . The mixture was extracted with TE saturated phenol, and after ethyl ether extraction, loaded onto a Sephadex G-50 (medium) column $(0.7 \times 30 \mathrm{~cm})$, which was eluted with TE. Fractions in the first peak showing the highest specific activity were pooled. The radioactivity was measured in a cocktail composed of $0.4 \%$ 2,5-diphenyloxazole and 0.02\% 1,4-bis[2-(5-phenyloxazolyl)benzene] in toluene by a Kontron MR300 liquid scintillation counter. The specific activity and an average molecular size of thus prepared DNA were approximately $10^{\circ} \mathrm{cpm} / \mu \mathrm{g}$ DNA and 300 base pairs (bp), respectively.

DNA-DNA Hybridization by the S1 Nuclease Method

The modification trials were based essentially on the procedures described by BARTH ${ }^{1)}$ and by COYKENDALL $^{5)}$. The sheared DNA was prepared by the sonic treatment for 3 minutes under dry ice-water cooling using Soniprep 150 (MSE Scientific Instruments). The reassociation reaction of Streptomyces DNA was performed at $65^{\circ} \mathrm{C}$, which was $25^{\circ} \mathrm{C}$ lower than its $\mathrm{Tm}$.

\section{Results and Discussion}

Denaturation of DNA in the Presence of Formamide

MCCONAUGHY $^{14)}$ reported that $1 \%$ increase of the formamide (FA) concentration lowered the $\mathrm{Tm}$ of a DNA duplex by $0.7^{\circ} \mathrm{C}$. We therefore first measured the Tm of Streptomyces and E. coli DNAs in $0.42 \mathrm{M} \mathrm{NaCl}$ versus various concentrations of FA (from 0 to $40 \% \mathrm{v} / \mathrm{v}$, ultra pure grade, Bethesda Res. Lab., Inc.) in Beckman DU-8 spectrophotometer equipped with the Tm system. As Fig. 1 indicates, exactly the same slope was obtained for Streptomyces and E. coli DNAs, and the Tm of native DNA in this solution was reduced by $0.53^{\circ} \mathrm{C}$ per increase of $1 \%$ FA. Furthermore, it was found that Streptomyces DNA was completely denatured in the presence of more than $20 \%$ FA 
Fig. 1. Tm of $S$. dimorphogenes DNA and $E$. coli DNA in the presence of formamide.

- $S$. dimorphogenes DNA, $O:$ E. coli DNA.

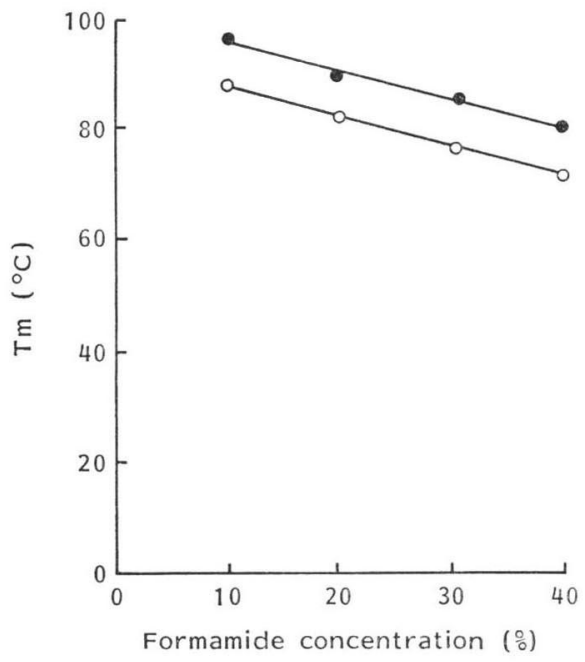

Table 1. Action of $\mathrm{S} 1$ nuclease on native and denatured $S$. dimorphogenes DNA in the presence of various formamide concentrations.

\begin{tabular}{ccc}
\hline \multirow{2}{*}{$\begin{array}{c}\text { Formamide } \\
(\%, v / v)\end{array}$} & \multicolumn{2}{c}{ DNA recovered by } \\
\cline { 2 - 3 } & TCA-precipitation $(\%)$ \\
\hline 0 & 100.0 & Denatured DNA \\
4 & 94.4 & 4.9 \\
8 & 88.1 & 5.0 \\
16 & 86.2 & 8.9 \\
\hline
\end{tabular}

NT: Not tested.

Duplicate $1 \mathrm{ml}$ of the reaction mixture consisted of $0.168 \mathrm{M} \mathrm{NaCl}, 1 \mathrm{~mm} \mathrm{ZnSO}_{4}, 30 \mathrm{~mm}$ of sodium acetate $(\mathrm{pH} 4.8), 20 \mu \mathrm{g}$ of sheared and denatured salmon sperm DNA, $5 \mathrm{U}$ of S1 nuclease, the given concentration of formamide as well as $50 \mathrm{ng}$ of labeled $S$. dimorphogenes DNA, either native or denatured. The mixture was incubated for 30 minutes at $65^{\circ} \mathrm{C}$. TCA-precipitated DNA was counted as described. Recovered DNA was expressed as a percentage of the amount obtained in the absence of FA (a value taken as 100 ).

by boiling for 5 minutes (data not shown).

Next, we examined the effect of FA on the S1 nuclease activity using native and denatured Streptomyces DNA as a substrate. As seen in Table 1, the addition of $8 \%$ FA elicited lesser reduction of the $\mathrm{S} 1$ nuclease activity than that of
Fig. 2. Effect of $\mathrm{S} 1$ nuclease on native and denatured $S$. dimorphogenes DNA.

$1 \mathrm{ml}$ of the reaction mixture (in duplicate) consisting of $0.168 \mathrm{M} \mathrm{NaCl}, 1 \mathrm{~mm} \mathrm{ZnSO}_{4}, 30 \mathrm{~mm}$ of sodium acetate $(\mathrm{pH} 4.8), 20 \mu \mathrm{g}$ of sheared and denatured salmon sperm DNA, $8 \%$ formamide, the given unit of S1 nuclease as well as $50 \mathrm{ng}$ of labeled $S$. dimorphogenes DNA, either native or denatured, was incubated at $65^{\circ} \mathrm{C}$. TCA-precipitated DNA was counted as described.

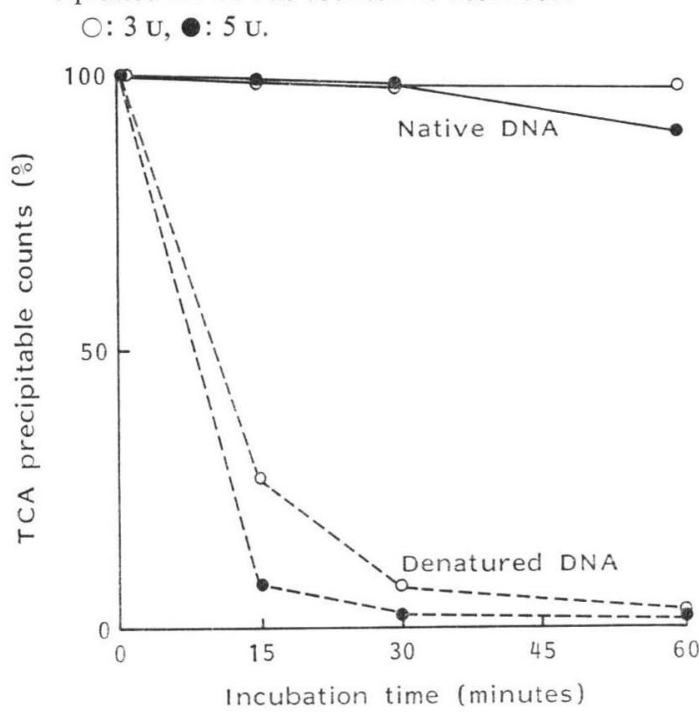

Fig. 3. Kinetics of $S$. dimorphogenes DNA reassociation.

Each hybridization mixture containing $20 \mathrm{ng}$ of labeled DNA and $10 \mu \mathrm{g}$ of unlabeled-sheared DNA. Other components and reaction conditions for the denaturation and reassociation are described in Results and Discussion.

$\mathrm{C}_{0}$ is the initial DNA concentration, and $\mathrm{C}$ is the SS-DNA concentration.

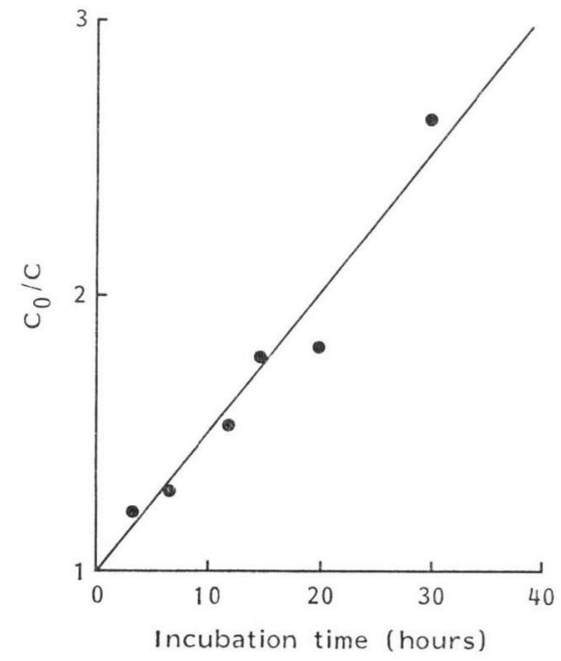


$16 \%$ FA, when judged by the recovery from denatured DNA. The reassociation reaction proceeded more favorably with $8 \% \mathrm{FA}$ than with $16 \% \mathrm{FA}$, as reported by CASEY and DAVIDSON ${ }^{15)}$. On the other hand, $4 \%$ FA that gave little effect on S1 nuclease activity was insufficient for the denaturation. Therefore, we chose $8 \%$ as the most suitable FA concentration.

\section{Effect of S1 Nuclease Concentration}

We tested the S1 nuclease concentration to optimize the activity of this enzyme so as to obtain not only the maximal hydrolysis of the single-stranded DNA (SS-DNA), but also the minimal hydrolysis of the double-stranded DNA (DS-DNA). The results in Fig. 2 show the time course of the S1 nuclease action measured at $65^{\circ} \mathrm{C}$. In the presence of $5 \mathrm{U}$ of this enzyme, the hydrolysis of SS-DNA was $98 \%$ by 30 minutes treatment whereas more than $97 \%$ of DS-DNA remained intact.

\section{Kinetics of Homoduplex Formation}

In order to find the reaction time for $50 \%$ reassociation $\left(\mathrm{C}_{0} \mathrm{t} 1 / 2\right)$ of $S$. dimorphogenes DNA, the kinetics of homoduplex formation was measured during the incubation at $65^{\circ} \mathrm{C}$. Fig. 3 shows that $\mathrm{C}_{0} \mathrm{t} 1 / 2$ was around 20 hours when the reaction mixture contained a 500:1 ratio of unlabeled DNA $(10 \mu \mathrm{g})$ and index DNA (20 ng). Thus, the incubation time for the reassociation reaction was set at 40 hours $\left(=2 \times \mathrm{C}_{0} t 1 / 2\right)$ taking into account the results of Coykendall and MUNZenMaier ${ }^{18)}$. It was also confirmed that this incubation time could be reduced to 16 hours when a 1,250:1 ratio of unlabeled DNA $(25 \mu \mathrm{g})$ and index DNA (20 ng) was used (data not shown), showing a good correspondence with the theoretical data obtained from the $\mathrm{C}_{0} \mathrm{t} 1 / 2$ analysis.

From the above findings, the reaction conditions for Streptomyces DNA hybridization using S1 nuclease were established as follows:

The reassociation mixture was made of $10 \mu \mathrm{g}$ of unlabeled-sheared DNA and $20 \mathrm{ng}$ of labeled DNA in $400 \mu \mathrm{l}$ of $0.42 \mathrm{M} \mathrm{NaCl}$ plus $20 \% \mathrm{FA}$ in a $5-\mathrm{ml}$ capped tube (siliconized). The mixture was denatured by boiling for 5 minutes, and then incubated for 40 hours at $65^{\circ} \mathrm{C}\left(2 \times \mathrm{C}_{0} \mathrm{t} 1 / 2\right.$ time $)$. After incubation, $600 \mu 1$ of $\mathrm{S} 1$ buffer (50 mm sodium acetate, $\mathrm{pH} 4.8,1.67 \mathrm{~mm} \mathrm{ZnSO}_{4}, 33 \mu \mathrm{g}$ of sheared and denatured salmon sperm DNA per $\mathrm{ml}$ ), and $5 \mathrm{U}$ of $\mathrm{S} 1$ nuclease were added. The mixture was further incubated for 30 minutes (at $65^{\circ} \mathrm{C}$ ) at which time the reaction was terminated by an addition of $1 \mathrm{ml}$ of cold $10 \%$ trichloroacetic acid (TCA). The mixture was kept on ice for 30 minutes. The precipitated DNA, which had been collected onto a Whatman GF/C filter, rinsed twice with $10 \mathrm{ml}$ of cold $5 \%$ TCA containing $200 \mu \mathrm{M}$ thymine and once with $2.5 \mathrm{ml}$ of acetone, was dried for 30 minutes at $65^{\circ} \mathrm{C}$ before counting in a scintillation cocktail.

This method has been successfuly employed for DNA homology comparison of $S$. dimorphogenes with Streptomyces olivaceus, Streptomyces nigrifaciens, Streptomyces plicatus and other strains ${ }^{7}$.

\section{References}

1) Barth, P. T. \& N. J. Grinter: Assay of deoxyribonucleic acid homology using a single-strand-specific nuclease at 75 C. J. Bacteriol. 121: 434 441, 1975

2) Tewfik, E. M. \& S. G. BRAdley: Characterization of deoxyribonucleic acids from streptomycetes and nocardiae. J. Bacteriol. 94: 1994 2000, 1967

3) Yamaguchi, T.: Similarity in DNA of various morphologically distinct actinomycetes. J. Gen. Appl. Microbiol. 13: 64 71, 1967

4) Farina, G. \& S. G. Bradley: Reassociation of deoxyribonucleic acids from Actinoplanes and other actinomycetes. J. Bacteriol. 102: 30 35, 1970 
5) Coykendall, A. L. \& A. J. Munzenmaier: Deoxyribonucleic acid hybridization among strains of Actinomyces viscosus and Actinomyces naeslundii. Int. J. Syst. Bacteriol. 29: 234 240, 1979

6) Marmur, J. \& P. Doty: Thermal renaturation of deoxyribonucleic acids. J. Mol. Biol. 3: 585 594, 1961

7) Watanabe, K.; T. Furumai, M. Sudoh, K. Yokose \& H. B. Maruyama: New $\alpha$-amylase inhibitor, trestatins. IV. Taxonomy of the producing strains and fermentation of trestatin A. J. Antibiotics 37: 479 486,1984

8) Yokose, K.; K. Ogawa, T. Sano, K. Watanabe, H. B. Maruyama \& Y. Suhara: New $\alpha$-amylase inhibitor, trestatins. I. Isolation, characterization and biological activities of trestatins A, B and C. J. Antibiotics 36: 1157 1165, 1983

9) Marmur, J.: A procedure for the isolation of deoxyribonucleic acid from micro-organisms. J. Mol. Biol. 3: 208 218, 1961

10) Chater, K. F.; D. A. Hopwood, T. Kieser \& C. J. Thompson: Gene cloning in Streptomyces. In Gene Cloning in Organisms Other than E. coli. Ed., Hofscheider, P. H. \& W. Goebel, pp. 69 95, Springer-Verlag, 1982

11) Shirahama, T.; T. Furumai \& M. Okanishi: A modified regeneration method for streptomycete protoplasts. Agric. Biol. Chem. 45: 1271 1273, 1981

12) Maniatis, T.; A. Jeffrey \& D. G. Kleid: Nucleotide sequence of the rightward operator of phage $\lambda$. Proc. Natl. Acad. Sci. U.S.A. 72: $1184 \sim 1188,1975$

13) Rigby, P. W. J.; M. Dieckmann, C. Rhodes \& P. Berg: Labeling deoxyribonucleic acid to high specific activity in vitro by nick translation with DNA polymerase I. J. Mol. Biol. 113: 237 251, 1979

14) McConaughy, B. L. M.; C.D. Laid \& B. J. MCCARthy: Nucleic acid reassociation in formamide. Biochemistry 8: 3289 3295, 1969

15) CASEY, J. \& N. Davidson: Rates of formation and thermal stabilities of RNA: DNA and DNA: DNA duplexes at high concentrations of formamide. Nucleic Acids Res. 4: 1539 1552, 1977

16) Coykendall, A. L. \& A. J. Munzenmaier: Deoxyribonucleic acid base sequence studies on glucanproducing and glucan-negative strains of Streptococcus mitior. Int. J. Syst. Bacteriol. 28: 511 515, 1978 